\title{
29. MOTION OF THE AUSTRALIAN PLATE FROM SEDIMENT PALEOINCLINATIONS, EARLY CRETACEOUS THROUGH HOLOCENE ${ }^{1}$
}

\author{
K. Kodama ${ }^{2}$ and J. G. Ogg ${ }^{3}$
}

\begin{abstract}
The change in paleolatitude of the areas off northwestern Australia since the Early Cretaceous was determined from paleomagnetism of cores from ODP Leg 123 (Sites 765 and 766) and DSDP Leg 27 (Site 261). The Early Cretaceous paleolatitudes determined for Sites 766 and 261 agree with each other, indicating an average paleolatitude of $37^{\circ} \pm 3^{\circ}$, which is slightly lower than expected from the Australian apparent polar wander path (APWP). The Early Cretaceous to Paleogene paleolatitudes for Site 765 are systematically lower than those predicted by the Australian apparent polar wander path. In particular, the disagreement between these data and predictions for the mid-to-Late Cretaceous is in excess of $15^{\circ}$.
\end{abstract}

\section{INTRODUCTION}

Leg 123 of the Ocean Drilling Program was undertaken in the Argo and Gascoyne abyssal plains in the eastern Indian Ocean, which lie between the Java Trench to the north and the northwestern margin of Australia to the south (Fig. 1). Analyses of marine magnetic anomalies (Larson, 1975; Heirtzler et al., 1978; Fullerton et al., 1989) and previous drilling of DSDP Leg 27 in the Argo Abyssal Plain (Veevers, Heirtzler, et al., 1974) suggested that the basins off northwestern Australia are among the oldest in the Indian Ocean, with an age for the oldest portion of Oxfordian to Kimmeridgian (150-160 Ma). Although DSDP Site 261 in the Argo Abyssal Plain $\left(12.9^{\circ} \mathrm{S}, 117.9^{\circ} \mathrm{E}\right)$ was penetrated down to basaltic basement, the recovery of sediment cores was poor $(20 \%$ on average), and the paleontological age of the basalt/sediment contact was not well constrained as Hauterivian-Valanginian to upper Oxfordian (Veevers, Heirtzler, et al., 1974).

Thus, the primary objectives of Leg 123 were (1) to recover a complete sedimentary section from the Late Jurassic to Holocene for elucidating the tectonic and paleoceanographic development of the Indian Ocean, (2) to improve the Late Jurassic to Early Cretaceous magnetobiostratigraphy for the Southern Hemisphere by correlating to the magnetic polarity time scale, as compiled from the Pacific and Atlantic-Tethys regions, and (3) to investigate the geochemistry and petrology of the oldest oceanic basement formed at the initial break-up of Gondwanaland. Site 765 of Leg 123 thus was placed near the ocean/continent boundary of the Argo Abyssal Plain and the Exmouth Plateau $\left(16.0^{\circ} \mathrm{S}, 117.6^{\circ} \mathrm{E}\right.$; $5730 \mathrm{mbsf}$ ), where a Late Jurassic marine magnetic anomaly lineation identified as Chron M25 (late Oxfordian) by Fullerton et al. (1989) trends in an east-northeast to west-southwest direction (Fig. 2). Site 766 was located at the foot of the western Exmouth Plateau $\left(19.9^{\circ} \mathrm{S}, 110.5^{\circ} \mathrm{E} ; 4008 \mathrm{mbsf}\right)$, about $10 \mathrm{~km}$ southeastward from Chron M10 of Fullerton et al. (1989). Thick sequences of Lower Cretaceous to Holocene strata, together with basaltic basement, were recovered at both sites. No Jurassic sediment, however, has been recognized from Site 765, the basal age of which was late Berriasian, while the age of the sediment/basalt

\footnotetext{
${ }^{1}$ Gradstein, F. M., Ludden, J. N., et al., 1992. Proc. ODP, Sci. Results, 123: College Station, TX (Ocean Drilling Program). Japan.

Department of Geology, Faculty of Science, Kochi University, Kochi 780 ,

${ }^{3}$ Department of Earth and Atmospheric Science, Purdue University, West Lafayette, IN, U.S.A.
}

interface of Site 766 was latest Valanginian, consistent with the basement age assigned by the magnetic anomaly lineation (Shipboard Scientific Party, 1990).

The main goal of this study is to compile the paleomagnetic results of Sites 765 and 766 of Leg 123 along with Site 261 of Leg 27 and then to obtain continuous records of paleolatitudes from Early Cretaceous to Holocene for the northwest Australian Plate. Magnetostratigraphy and paleolatitudes for the Lower Cretaceous sections of the three sites also are presented by Ogg et al. in this volume. Here, we summarize the relationship of paleolatitudes vs. age for these three sites and, in particular, present Early Cretaceous through Holocene paleolatitude changes for Site 765, based upon the shore-based analyses of the Late Cretaceous and younger sediments.

\section{MEASUREMENTS AND DATA ANALYSIS}

Directions of natural remanent magnetization (NRM) and those after alternating field (AF) demagnetization were measured on board the ship for almost all of the archive halves of cores of

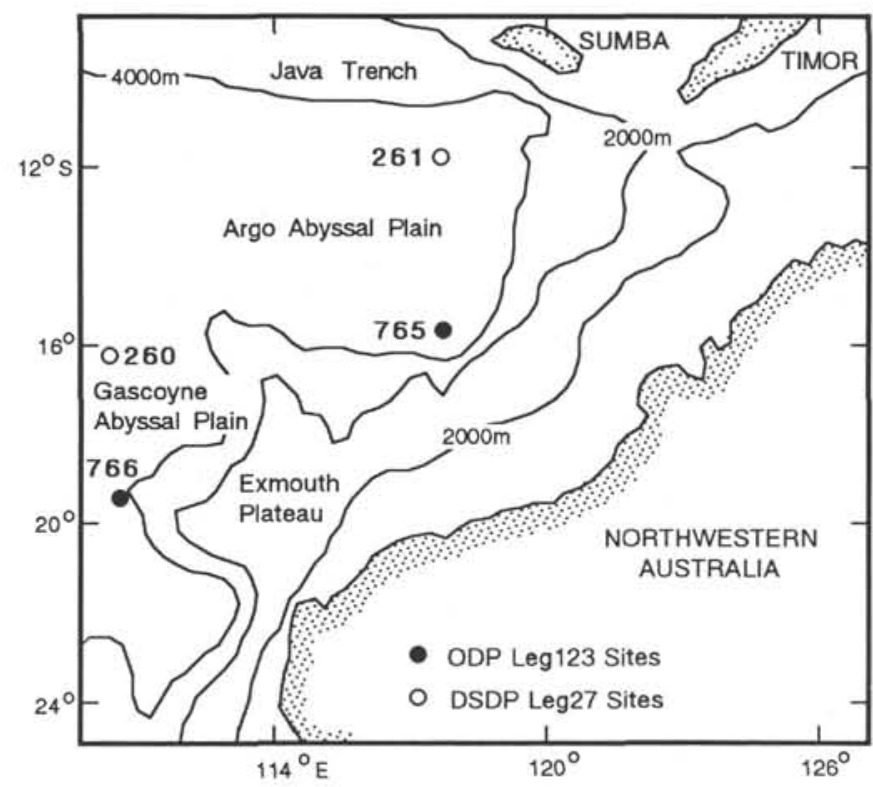

Figure 1. Locations of drill sites of ODP Leg 123 and DSDP Leg 27 in the Argo and Gascoyne abyssal plains off northwestern Australia. 


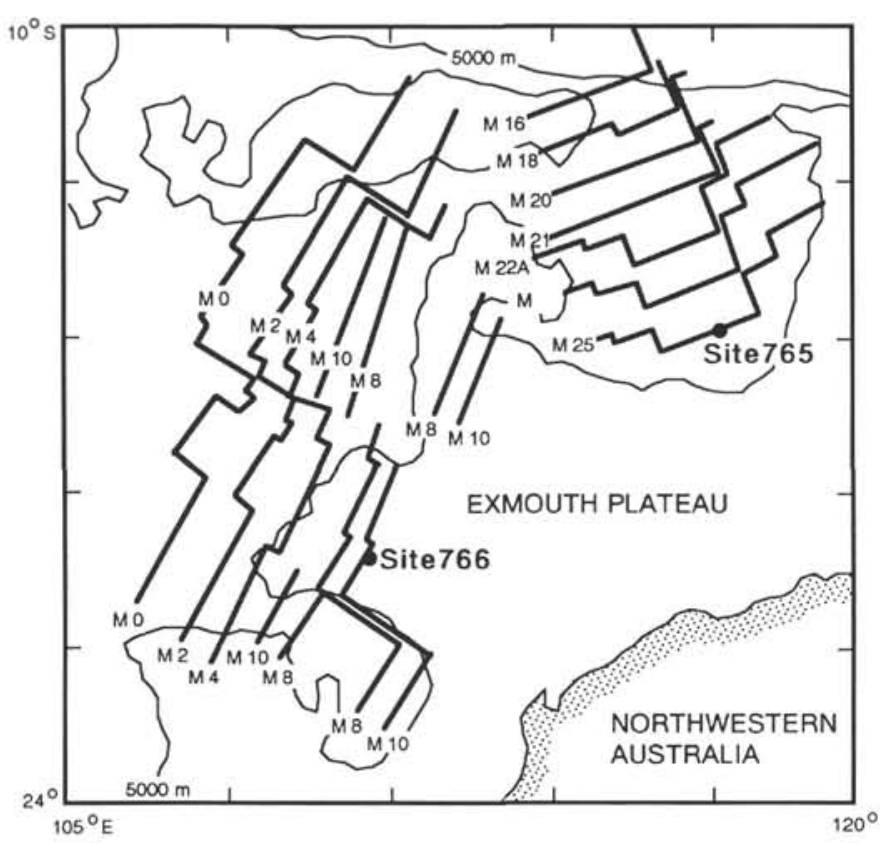

Figure 2. Geomagnetic isochrons in the Argo and Gascoyne abyssal plains, after Fullerton et al. (1989).

sediments and igneous rocks recovered from Sites 765 and 766. Measurements were performed with a $5-\mathrm{cm}$ interval using the automated long-core cryogenic magnetometer with its three-axis AF demagnetization coils on board the JOIDES Resolution. Demagnetization was done routinely at two steps of 10 and $15 \mathrm{mT}$ and, if necessary, at additional levels of 20 and $25 \mathrm{mT}$. Results of these shipboard measurements are detailed in the Initial Reports of Leg 123 (Ludden, Gradstein, et al., 1990). Although these preliminary measurements were suitable for obtaining the approximate pattern of geomagnetic polarity zonation, the detailed polarity interpretation and the precise calculation of paleolatitudes were done only on the basis of shore-based measurements of individual discrete samples, coupled with more careful $\mathrm{AF}$ and thermal demagnetization treatments.

\section{SAMPLING}

On average, three oriented cylindrical core specimens $(2.5 \mathrm{~cm}$ in diameter and 2.3 to $2.5 \mathrm{~cm}$ long) were cut from the 1.5 -m-long split core section of Lower Cretaceous sequences of Holes 765C and 766A. An average of one minicore or oriented cubic specimen (2.2 cm long) sliced by a double-saw was sampled for Upper Cretaceous and younger well-consolidated sediments. All of these samples, upon cutting, were sealed in aluminum foil to prevent drying and contamination during transportation and storage. Plastic cube boxes $(2 \times 2 \times 1.9 \mathrm{~cm}$ in size) were used for sampling unconsolidated soft sediments. Intervals of obvious slumping or strong disturbance were avoided in general. Samples from the Lower Cretaceous to Uppermost Jurassic cores of DSDP Site 261 were collected in a similar manner at the West Coast Core Repository prior to the Leg 123 cruise (Ogg et al., this volume). An average of one minicore of the same size as the sediment samples was drilled from each different flow unit of basaltic basement of Holes $765 \mathrm{C}$ and $765 \mathrm{D}$. The thick diabase sill of Hole $766 \mathrm{~A}$ was sampled at 1 - to $1.5-\mathrm{m}$ intervals.

Because the Lower Cretaceous sections of Hole $765 \mathrm{C}$ deviate from vertical by approximately $10^{\circ}$, the azimuth orientation of samples with respect to the direction of the apparent dip of bedding was recorded for correcting the drill-hole deviation in the final data analysis, as detailed by Ogg (1988) and Ogg et al. (this volume).

The total number of discrete samples of sediments thus collected is 258 for Hole $765 \mathrm{C}, 301$ for Hole $766 \mathrm{~A}$, and 47 from Site 261. Igneous rock samples are 5 for Hole 765C, 59 for Hole 765D, and 52 for Hole 766A.

\section{MEASUREMENTS}

Prior to Leg 123, samples from Site 261 were measured using a two-axis ScT cryogenic magnetometer at the California Institute of Technology and at the University of Wyoming, both sets of equipment housed in a magnetically shielded environment. This shore-based study of Site 261 samples and the shipboard preliminary analysis of several pilot samples from Leg 123 suggested that the reddish claystones dominating the Lower Cretaceous sections were demagnetized efficiently only by thermal demagnetization. Samples from sedimentary sections of Leg 123, therefore, were divided according to lithology and were measured at two different paleomagnetic laboratories. All the Lower Cretaceous samples from Hole $765 \mathrm{C}$ and part of the Site 261 samples were measured at the University of Wyoming, where a thermal demagnetizer having large-capacity heating and cooling chambers is available. The rest of the Hole $765 \mathrm{C}$ samples and all the samples from Hole $766 \mathrm{~A}$ were analyzed using an automated three-axis $2 \mathrm{G}$ cryogenic magnetometer and an AF demagnetizer with a three-axis sample tumbler at the paleomagnetic laboratory at Kochi University. All volcanic rock samples were measured with a computer-facilitated Schonstedt SSM-2 spinner magnetometer at Kochi University.

\section{DATA ANALYSIS}

Each sample, whether sedimentary or volcanic, was subjected to progressive AF or thermal demagnetization to isolate the direction of characteristic magnetization. Pilot samples of sediments were selected from each different lithology or from sections of different biostratigraphic age. Pilots from Hole 766A were subjected to detailed AF demagnetization with peak intensities of 1 , $2.5,5,7.5$, and 10 to $45 \mathrm{mT}$, with increments of $5 \mathrm{mT}$, and those from Hole $765 \mathrm{C}$ and Site 261 were thermally demagnetized at $100^{\circ}$ to $650^{\circ} \mathrm{C}$, with increments of $50^{\circ} \mathrm{C}$.

Based on these pilot analyses, the reddish claystones from the Lower Cretaceous strata of Hole $765 \mathrm{C}$ and Site 261 were demagnetized at $350^{\circ} \mathrm{C}$, and between $450^{\circ}$ and $650^{\circ} \mathrm{C}$, incremented by $50^{\circ} \mathrm{C}$, with an additional treatment at $665^{\circ} \mathrm{C}$ if necessary. Progressive AF demagnetizations at $2.5,5,7.5 \mathrm{mT}$, and 10 to $45 \mathrm{mT}$ with an interval of $5 \mathrm{mT}$ were accomplished for all the Upper Cretaceous and younger sediments from Hole $765 \mathrm{C}$. The routine $\mathrm{AF}$ demagnetization for regular samples from Hole 766A consisted of $10,20,30,35,40$, and $45 \mathrm{mT}$, and, if required, additional thermal demagnetization at $300^{\circ}$ and $400^{\circ} \mathrm{C}$ were performed. All the igneous rock samples from Holes 765C, 765D, and 766A were subjected to stepwise AF demagnetization at $2.5,5,7.5 \mathrm{mT}$, and 10 to $45 \mathrm{mT}$, incremented by $5 \mathrm{mT}$.

Directions of NRM after progressive demagnetization were plotted sample by sample on a Zijderveld diagram (Zijderveld, 1967) to assign polarity and to select vector endpoints displaying univectorial decay, preferably to the origin, by visual inspection. Typical examples of the diagram are shown in Figure 3. The characteristic magnetization direction for each sample was calculated by applying the three-dimensional principal component analysis of Kirschvink (1980) to the set of vectors thus selected. The reliability of each characteristic direction was estimated based upon the criteria of Ogg et al. (this volume). The characteristic directions assigned to the two ratings (N or R, and NP or RP) of high reliability were used for further analysis of paleolatitudes. Directions of the highest reliability with ratings of $\mathrm{N}$ or $\mathrm{R}$ were given double the weight of the other rating. 
A w, Up
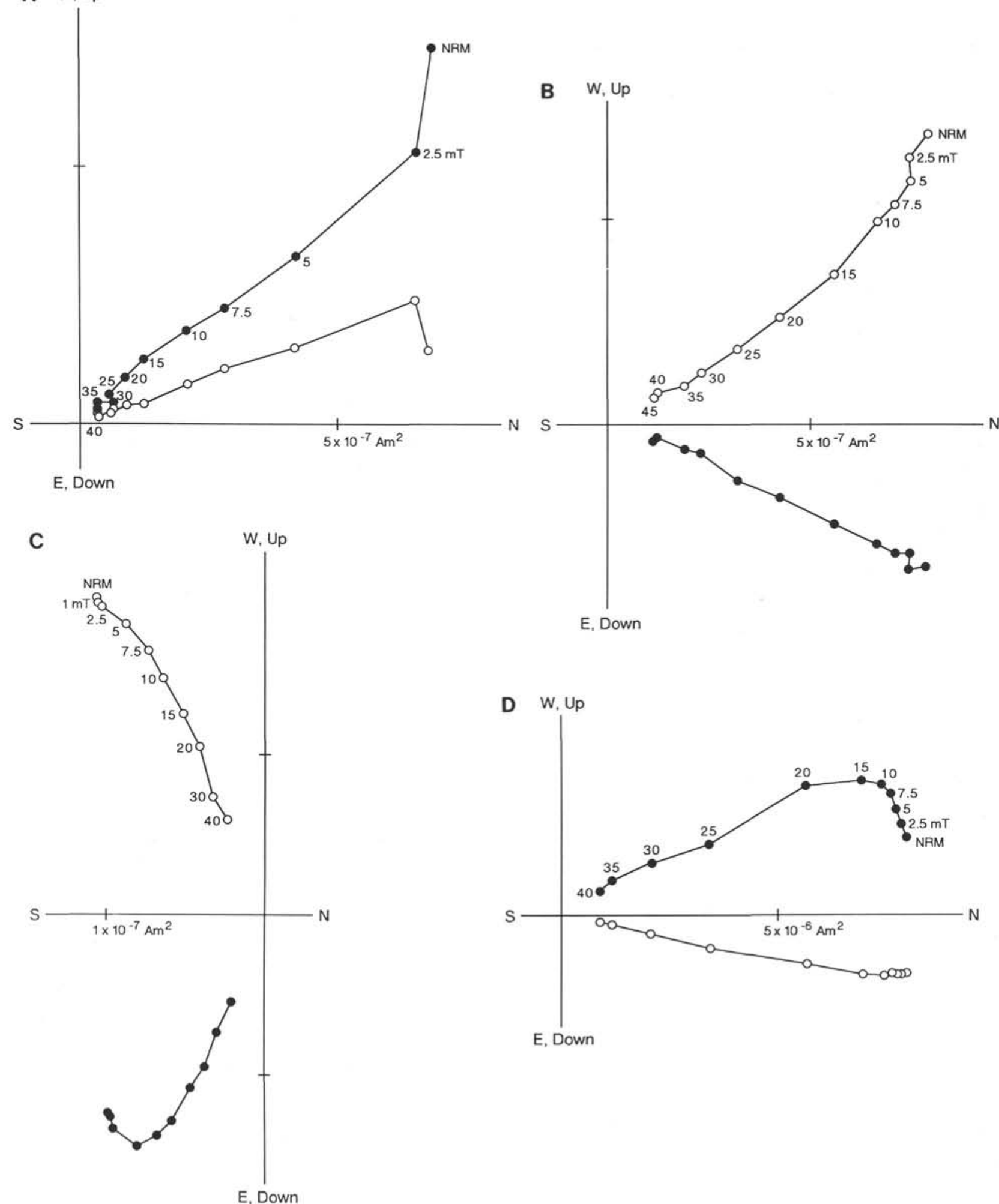

E, Down

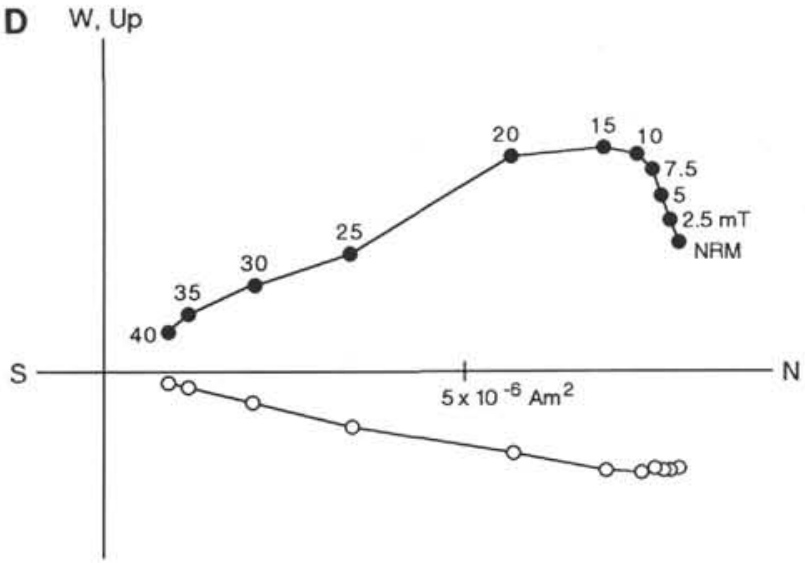

E, Down

Figure 3. Orthogonal plots of magnetization vectors of typical samples during progressive AF demagnetization. Solid circles represent projections on the horizontal plane, and open circles show projections on the vertical plane. Declination is arbitrary because of no orientation control. A. Albian zeolitic clay; Sample 123-765C-27R-1, 139-141 cm. Normal polarity, with characteristic direction (D = $311^{\circ}, \mathrm{I}=-9^{\circ}$ ) obtained by least-squares computation using 5- through 40-mT steps. B. Aptian claystone; Sample 123-765C-43R-6, $30-32 \mathrm{~cm}$. Normal polarity, with characteristic direction $\left(D=23^{\circ}, I=-40^{\circ}\right)$ from 7.5 through $45 \mathrm{mT}$. C. Hauterivian claystone; Sample 123-766-32R-5, 82-84 cm. Normal Polarity, with characteristic direction $\left(D=229^{\circ}, I=-32^{\circ}\right)$ from 7.5 through $40 \mathrm{mT}$. D. Aphyric pillow basalt; Sample 123-765D-26R-1, 28-30 cm. Reversed polarity, with characteristic direction $\left(\mathrm{D}=348^{\circ}, \mathrm{I}=10^{\circ}\right)$ from 20 through $40 \mathrm{mT}$. 
Because none of the cores was oriented relative to a northern azimuth, special statistics using only inclination data must be applied to obtain an unbiased, true, mean inclination and associated precision parameters. Several methods have been proposed for such calculations (Briden and Ward, 1966; Kono, 1980; McFadden and Reid, 1982; Cox and Gordon, 1984), all of which give similar results. The statistical method of Kono (1980) was applied in this study because solutions to its simple, nonlinear simultaneous equations can easily be obtained by a conventional iteration (Newton's method). The mean inclinations and associated errors relative to the axis of the drill hole were calculated for different biostratigraphic age intervals for the sediments, while a single estimate was obtained for the igneous basement samples.

\section{PALEOLATITUDES OF LEG 123 SEDIMENTS}

\section{Mean Inclinations}

For sediments of each site, mean inclinations for different time intervals were computed separately for normal and reversed polarity, and for all samples having mixed polarity. Because of the small number of basement samples measured, the mean inclination was calculated for all samples with combined polarity. These results are summarized for each site in Table 1, where deviation of cores from vertical was corrected for the mean inclinations of Sites 765 and 766 . For most suites of sediment samples, the mean inclination of normal polarity was antipodal to that of reversed polarity within error limits, which means that there was no significant secondary overprint. Apart from the Lower Cretaceous, reddish-colored sediments from Sites 261 and 765 , which required thermal demagnetization at temperatures higher than $350^{\circ} \mathrm{C}$ to remove secondary components, most of the sediments, irrespective of polarity, had stable characteristic directions showing univectorial decay to the origin by applying AF demagnetization higher than $10 \mathrm{mT}$ (Ogg et al., this volume). Detailed AF demagnetization treatments for basement samples indicated that most carried a significant amount of secondary, possibly presentday, overprinting, which, however, could be easily removed by $\mathrm{AF}$ treatments up to $7.5 \mathrm{mT}$. Each basalt sample also had a single and stable component, although their directions as a whole were scattered (Kodama, unpubl. data). This probably occurs because some samples may have been taken from a brecciated portion of the basalt flow and because the volcanics were extruded episodi-

Table 1. Summary of paleolatitudes for ODP Sites 765 and 766 and DSDP Site 261.

\begin{tabular}{|c|c|c|c|}
\hline $\begin{array}{l}\text { Age } \\
(\mathrm{Ma})\end{array}$ & $\begin{array}{c}\text { Number of } \\
\text { samples }\end{array}$ & $\begin{array}{l}\text { Paleolatitude } \\
\left({ }^{\circ} \mathrm{S}\right)\end{array}$ & $\begin{array}{c}\alpha_{95} \\
\text { (degrees) }\end{array}$ \\
\hline \multicolumn{4}{|l|}{ Site 765} \\
\hline Paleogene & 22 & 18.4 & 7.2 \\
\hline Maestrichtian-Cenomanian & 27 & 24.8 & 3.2 \\
\hline Albian & 22 & 21.3 & 5.0 \\
\hline Aptian & 28 & 30.4 & 4.0 \\
\hline Barremian & 70 & 26.4 & 2.6 \\
\hline Hauterivian & 24 & 28.3 & 4.5 \\
\hline Berriasian-Valanginian & 65 & 33.3 & 4.1 \\
\hline Basement & 20 & 74.3 & 20.6 \\
\hline \multicolumn{4}{|l|}{ Site 766} \\
\hline Barremian & 53 & 32.1 & 3.0 \\
\hline Hauterivian & 38 & 39.5 & 4.2 \\
\hline Valanginian-Hauterivian & 118 & 37.0 & 2.6 \\
\hline \multicolumn{4}{|l|}{ Site 261} \\
\hline Barremian & 21 & 36.9 & 6.6 \\
\hline Valanginian-Hauterivian & 9 & 39.0 & 5.1 \\
\hline Tithonian-Berriasian & 17 & 34.8 & 4.9 \\
\hline
\end{tabular}

cally, resulting in incomplete time-averaging of paleosecular variations.

\section{PREVIOUS STUDIES OF AUSTRALIAN POLAR WANDER PATH}

Since the pioneer work by Irving (1956), numerous paleomagnetic studies were conducted in Australia on the Precambrian (e.g., Porath, 1967; Giddings, 1976; Embleton, 1978), the Paleozoic (e.g., Irving, 1966; Luck, 1973; Embleton and Shepherd, 1977), the Mesozoic (e.g., Robertson, 1963; Schmidt, 1976; Embleton and Schmidt, 1977), and the Cenozoic (e.g., Wellman et al., 1969; McElhinny et al., 1974; Idnurm, 1985). The whole Paleozoic to Cenozoic apparent polar wander path (APWP) for Australia was reviewed by Embleton $(1981,1984)$.

The Mesozoic and Cenozoic APWP for Australia indicates a net northward drift of approximately $35^{\circ}$ in latitude, but exhibits a trajectory more irregular than that reported for India (e.g., Klootwijk, 1984). The complex APWP has been interpreted as having been caused by incomplete time-averaging of remanence directions of volcanic rocks, from which most Mesozoic and Cenozoic data were derived (Idnurm, 1985). The late MesozoicCenozoic APWP for Australia had been redetermined by studies of sedimentary rock sequences (Idnurm, 1985) and of laterites and weathered profiles (Schmidt and Embleton, 1976; Idnurm and Senior, 1978; Embleton and McElhinny, 1982), displaying a smooth meridional trajectory. According to the overall averaged APWP of Embleton $(1981,1984)$, Australia had experienced a large clockwise rotation of about $45^{\circ}$ between the OxfordianTithonian (150-130 Ma) and the late Mesozoic, although the detailed form of the Cenozoic and the early Mesozoic portions of the APWP is not well constrained.

\section{DISCUSSION}

The predicted paleolatitudes for ODP Sites 765, 766 and DSDP Site 261, calculated from the revised Mesozoic and Cenozoic APWP of Embleton (1984), are listed in Table 2. Figure 4 illustrates the change of paleolatitude with time, for Sites 765, 766 and 261 , as tabulated in Table 1 , together with that predicted by Embleton (1984) for each site.

The paleolatitudes of Site 765 , determined for the long time range from the Berriasian-Valanginian to Paleogene, as a whole seem to decrease with time. Although no latitudinal change of statistical significance during the Early Cretaceous is recognizable; there may be a significant difference in paleolatitudes between the Berriasian-Aptian and later ages. It is evident from the plot in Figure 4 that the mean paleolatitude for each time interval is consistently lower than that observed for the other two sites or that computed by the Australian APWP. The discrepancy between the observed and predicted paleolatitudes cannot be explained even by assuming a primary dip of strata for Site 765 when correcting the hole deviation from vertical. As detailed in Ogg et

Table 2. Paleolatitudes for ODP Sites 765 and 766 and DSDP Site 261 predicted by the Australian apparent polar wander path since the Early Cretaceous.

\begin{tabular}{lccc}
\hline \multirow{1}{c}{$\begin{array}{c}\text { Age } \\
\text { (Ma) }\end{array}$} & \multicolumn{3}{c}{ Paleolatitude $\left({ }^{\circ} \mathrm{S}\right)$} \\
\hline Miocene (20) & Site 765 & Site 766 & Site 261 \\
Eocene-Paleocene (58) & 29.0 & 32.7 & 25.9 \\
Campanian (80) & 44.0 & 47.6 & 41.0 \\
Cenomanian-Turonian (90) & 52.6 & 53.8 & 49.8 \\
Albian (105) & 44.9 & 45.4 & 42.2 \\
mid-Hauterivian (115) & 41.3 & 40.8 & 38.9 \\
earliest Berriasian (128) & 44.7 & 42.2 & 42.7 \\
\hline
\end{tabular}




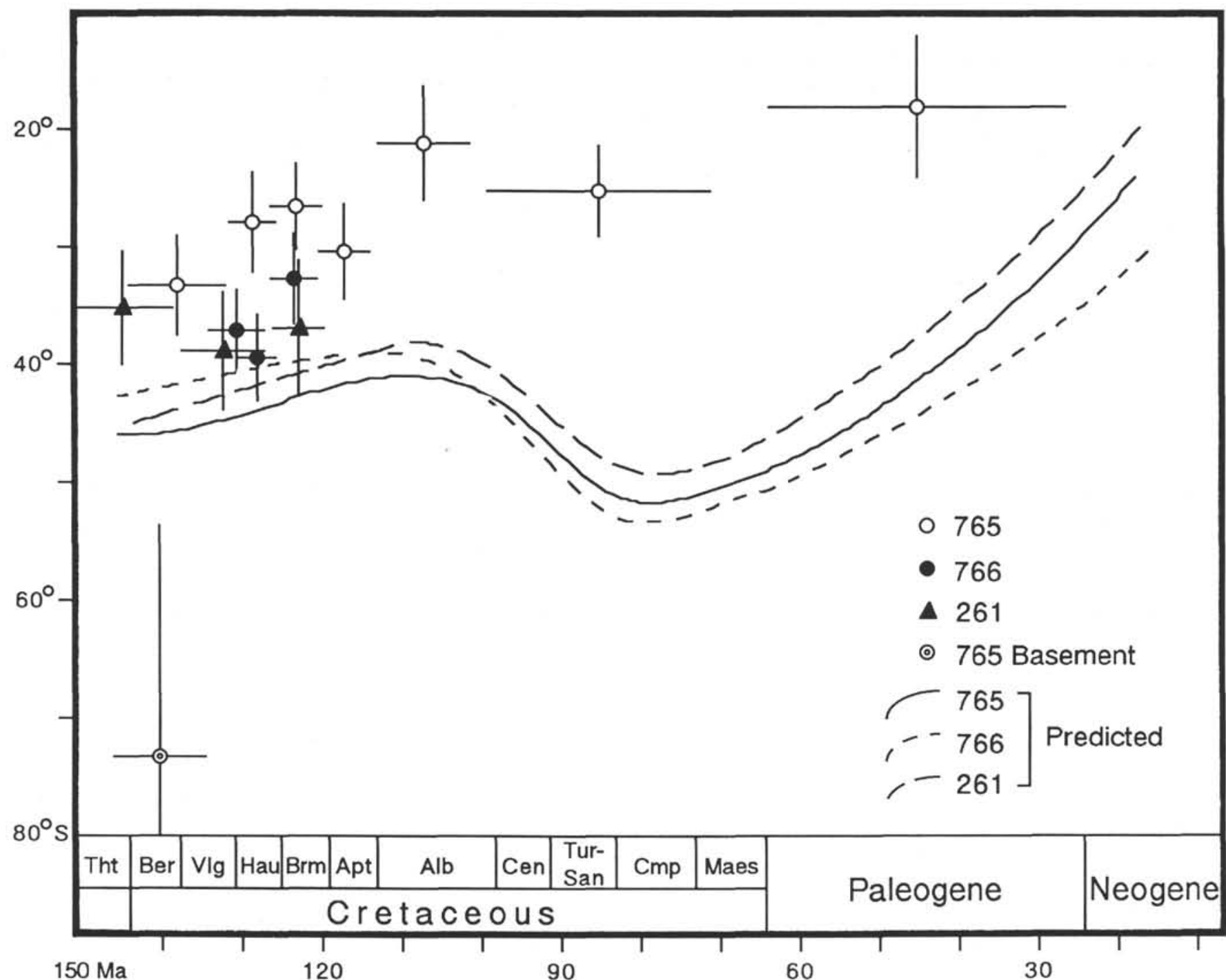

Figure 4. Plot of paleolatitude vs. age. Vertical bars are the $95 \%$ confidence error limits, and horizontal bars are the range of biostratigraphic ages of the horizons used to calculate the paleolatitude. Solid line shows paleolatitude change for Site 765, dashed line indicates that for Site 766, and broken line represents that of Site 261, each being predicted by the Australian apparent polar wander path (after Embleton, 1984).

al. (this volume), by including an additional $5^{\circ}$ primary dip for the correction, the mean paleolatitude in the Early Cretaceous is $33.8^{\circ} \mathrm{S}$, which is only slightly lower than those for the other two sites. However, for the later ages, the significant discrepancy in excess of $10^{\circ}$ in latitude still remains after correction for the primary dip. The mean paleolatitude computed for the basalt basement of Hole $765 \mathrm{C}$, although accompanied by a large error, is considerably higher than for the sediments. Detailed comparison of paleolatitudes determined from paleomagnetism of DSDP sediments in the Pacific to a reference frame based on nonsediment data suggests that the sediment paleolatitudes are systematically lower than those predicted by up to $10^{\circ}$ (Gordon, 1990). Therefore, the possible factor responsible for this discrepancy might be an inclination shallowing during diagenetic compaction (e.g., Blow and Hamilton, 1978). In this case, the paleolatitudes for Site 765 might be regarded as a minimum estimate of the latitudinal drift of this part of the Australian Plate. Another possible explanation for this disagreement might be that seafloor spreading occurring off northwestern Australia during the Cretaceous moved the Argo Basin northward from Australia. This possibility, however, is unlikely because no evidence suggests such an ancient spreading center in the northwestern continental margin of Australia (e.g., Veevers et al., 1985). Another explanation is that the discrepancy was caused by the lack of reliable data about the Cretaceous Australian APWP. This is plausible because most of the Mesozoic data were derived from igneous rocks (e.g., Embleton, 1981), which gave incomplete time-averaging of geomagnetic fields (Idnurm, 1985).

No significant difference occurs in the Early Cretaceous paleolatitudes for Sites 766 and 261. It seems that the mean paleolatitudes are slightly smaller than those predicted for the contemporaneous age. In this case, however, inclination shallowing that reflects sediment facies difference (e.g., Celaya and Clement, 1988 ) is unlikely because the paleolatitudes from the dark greenish-gray siltstone of Site 766 agree with those from the reddish claystone of Site 261 . The discrepancy, approximately $5^{\circ}$, between the observed and predicted paleolatitudes, therefore, seems to be real. According to the paleogeographic reconstruction of the Indian Ocean by Besse and Courtillot (1988), the paleoposition of the region off northwestern Australia at the early Barremian age was approximately $35^{\circ} \mathrm{S}$, which is in good agreement with those computed for ODP Sites 765, 766, and DSDP Site 261. 


\section{ACKNOWLEDGMENTS}

We are grateful to the Ocean Drilling Program for enabling us to participate during Leg 123. This study was supported by the Japan Office of Ocean Drilling Program and Grant-in-Aid for Scientific Research, the Ministry of Education, Science and Culture (No. 62420015) (KK) and by a grant from the U.S. Science Support Program (JGO). We thank Joseph Kirschvink (Caltech), Peter Shive, and Maureen Steiner (University of Wyoming) for allowing us to use their paleomagnetic facilities. Measurements were performed by Brian Wallick at Caltech and University of Wyoming, and by Marie Bowyer, Sachiko Shiota, Michihiko Nishibayashi, and Takashi Ishihara at Kochi University.

\section{REFERENCES}

Besse, J., and Courtillot, V., 1988. Paleogeographic maps of the continents bordering the Indian ocean since the early Jurassic. J. Geophys. Res., 93:11791-11808.

Blow, R. A., and Hamilton, N., 1978. Effect of compaction on the acquisition of a detrital remanent magnetization in fine grained sediments. Geophys. J. R. Astron. Soc., 52:13-23.

Briden, J. C., and Ward, M. A., 1966. Analysis of magnetic inclination in bore cores. Pure Appl. Geophys., 63:133-152.

Celaya, M. A., and Clement, B. M., 1988. Inclination shallowing in deep sea sediments from the North Atlantic. Geophys. Res. Lett., 15:52-55.

Cox, A., and Gordon, R. G., 1984. Paleolatitudes determined from paleomagnetic data from vertical cores. Rev. Geophys. Space Phys., 22:4772.

Embleton, B.J.J., 1978. The paleomagnetism of 2400 m.y. old rocks from the Australian Pilbara craton and its relation to Archaean-Proterozoic tectonics. Precambrian Res., 6:275-291.

1981. A review of the paleomagnetism of Australia and Antarctica. In McElhinny, M. W., and Valencio, D. A., Paleoreconstruction of the Continents. Geodyn. Ser., 2:77-92.

1984. Continental palaeomagnetism. In Veevers, J. J., Phanerozoic Earth History of Australia: Oxford (Oxford University Press), 11-16.

Embleton, B.J.J., and Schmidt, P. W., 1977. Revised palaeomagnetic data for the Australian Mesozoic and a synthesis of late Palaeozoic-Mesozoic results for Gondwanaland. Tectonophysics, 38:355-364.

Embleton, B.J.J., and Shepherd, J., 1977. The Late Devonian palaeomagnetic field for southeastern Australia: A new result for the Lochiel Formation and a reassessment of results from the Catombal Group. $J$. Geophys. Res., 82:5423-5426.

Embleton, B.J.J., and McElhinny, M. W., 1982. Marine magnetic anomalies, palaeomagnetism and the drift history of Gondwanaland. Earth Planet. Sci. Lett., 58:141-150.

Fullerton, L. G., Sager, W. W., and Handschumacher, D. W., 1989. Late Jurassic-Early Cretaceous evolution of the eastern Indian Ocean adjacent to Northwest Australia. J. Geophys. Res., 94:2937-2953.

Giddings, J. W., 1976. Precambrian palaeomagnetism in Australia I: basic dykes and volcanics from the Yilgarn Block. Tectonophysics, 30:91108.

Gordon, R. G., 1990. Test for bias in paleomagnetically determined paleolatitudes from Pacific Plate Deep Sea Drilling Project sediments. J. Geophys. Res., 95:8397-8404.

Heirtzler, J. R., Cameron, P., Cook, P. J., Powell, T., Roeser, H. A., Sukardi, S., and Veevers, J. J., 1978. The Argo Abyssal Plain. Earth Planet. Sci. Lett., 41:21-31.
Idnurm, M., 1985. Late Mesozoic and Cenozoic palaeomagnetism of Australia-I. A redetermined apparent polar wander path. Geophys. J. R. Astron. Soc., 83:399-418.

Idnurm, M., and Senior, B. R., 1978. Palaeomagnetic ages of Late Cretaceous and Tertiary weathered profiles in the Eromanga Basin, Queensland. Palaeogeog., Palaeoclim., Palaeoecol., 24:263-277.

Irving, E., 1956. The magnetization of the Mesozoic dolerites of Tasmania. Proc. Royal Soc. Tasmania, 90:157-168.

1966. Palaeomagnetism of some Carboniferous rocks from New South Wales and its relation to geological events, J. Geophys. Res., 71:6025-6051.

Kirschvink, J. L., 1980. The least-squares line and plane and the analysis of palaeomagnetic data, Geophys. J. R. Astron. Soc., 62:699-718.

Klootwijk, C. T., 1984. A review of Indian Phanerozoic palaeomagnetism: implications for the India-Asia collision. Tectonophysics. 105:331-353.

Kono, M., 1980. Statistics of paleomagnetic inclination data. J. Geophys. Res., 85:3878-3882.

Larson, R. L., 1975. Late Jurassic sea-floor spreading in the eastern Indian Ocean. Geology, 3:69-71.

Luck, G. R., 1973. Palaeomagnetic results from Palaeozoic rocks of southeast Australia. Geophys. J. R. Astron. Soc., 32:35-52.

Ludden, J. N., Gradstein, F. M., et al., 1990. Proc. ODP, Init. Repts., 123: College Station, TX (Ocean Drilling Program).

McElhinny, M. W., Embleton, B.J.J., and Wellman, P., 1974. A synthesis of Australian Cenozoic palaeomagnetic results. Geophys. J.R. Astron. Soc., 36:141-151.

McFadden, P. L., and Reid, A. B., 1982. Analysis of palaeomagnetic inclination data. Geophys. J. R. Astron, Soc., 69:307-319.

Ogg, J. G., 1988. Early Cretaceous and Tithonian magnetostratigraphy of the Galicia margin (Ocean Drilling Program Leg 103). In Boillot, G., Winterer, E. L., et al., Proc. ODP, Sci. Results, 103: College Station, TX (Ocean Drilling Program), 659-682.

Porath, H., 1967. Palaeomagnetism and the age of Australian hematite ore bodies. Earth Planet. Sci. Lett., 2:409-414.

Robertson, W. A., 1963. Palaeomagnetism of some Mesozoic intrusives and tuffs from eastern Australia. J. Geophys. Res., 68:2299-2312.

Schmidt, P. W., 1976. A new palaeomagnetic investigation of Mesozoic igneous rocks in Australia. Tectonophysics, 33:1-13.

Schmidt, P. W., and Embleton, B.J.J., 1976. A new palaeomagnetic investigation of Mesozoic igneous rocks in Australia. Tectonophysics, 33:1-13.

Shipboard Scientific Party, 1990. Sites 765 and 766. In Gradstein, F. M., Ludden, J., et al., Proc. ODP, Init. Repts., 123: College Station, TX (Ocean Drilling Program), 63-352.

Veevers, J. J., Heirtzler, J. R., et al., 1974. Init. Repts. DSDP, 27: Washington (U.S. Govt. Printing Office).

Veevers, J. J., Tayton, J. W., and Johnson, B. D., 1985. Prominen magnetic anomaly along the continent-ocean boundary between the northwestern margin of Australia (Exmouth and Scott Plateaus) and the Argo Abyssal Plain. Earth Planet. Sci. Lett., 72:415-426.

Wellman, P., McElhinny, M. W., and McDougall, I., 1969. On the polar wander path for Australia during the Cenozoic. Geophys. J. R. Astron. Soc., 18:371-395.

Zijderveld, J.D.A., 1967. AC demagnetization of rocks: analysis of results. In Collinson, D. W., Creer, K. M., and Runcorn, S. K. (Eds.), Methods in Palaeomagnetism: Amsterdam (Elsevier), 254-286.

Date of initial receipt: 16 July 1990

Date of acceptance: 14 May 1991

Ms 123B-129 